重篤な合併症を有した高齢者悪性リンパ腫の 3 症例

永 沼 久夫

\title{
Three Cases of Malignant Lymphoma with Severe \\ Complications in the Elderly
}

\author{
Hisao Naganuma \\ (Kofu Kyouritu Hospital)
}

\begin{abstract}
Three recent cases of malignant lymphoma with severe complications in the elderly are presented. Case 1: An 80-year-old man with liver cirrhosis, chronic hepatitis B, old tuberculosis and diabetes mellitus was hospitalized because of febricula and swelling of abdominal and cervical lymph nodes. Lymph node biopsy revealed malignant lymphoma (pleomorphic type). After the first cycle of COD-BLAMIV chemotherapy, the varix ruptured. Chemotherapy was stopped because of his performance status and complications. Case 2: A 70-year-old man with chronic obstructive lung disease was hospilized because of abdominal and cervical lymph nodes swelling. He had malignant lymphoma (Hodgkin's disease) and gastric carcinoma. Total gastrectomy was performed after 3 cycles COPP/ABV hybrid chemotherapy, but he died of MRSA infection. Case 3 : A 65-year-old woman with liver cirrhosis, chronic hepatitis $C$ and esophageal varix was hospitalized because of a submandibular mass. After surgery, COD-BLAMIV chemotherapy was started since the pathological diagnosis was malignant lymphoma (diffuse large cell). In these three cases, recombinant human granulocyte colony-stimulating factor was effective for neutropenia. We recognize the necessity of evaluation and special care of senile mental disturbance. And we are confident that positive treatment for the elderly is possible based on suffcient prechemotherapy evaluation.
\end{abstract}

Key word : malignant lymphoma, severe complications, the elderly

\section{緒 言}

悪性リンパ腫は化学療法の有効な疾患であるが高歯者 に対する化学療法は, 予測生存期間, 合併症, 患者をと りまく社会環境などのために対症的あるいは消極的にな りがちである1) 4)。また QOL の観点からも一概に積極 的な治療のみ肯定し得ない.今回我々は重篤な合併症を かかえる高齢者の悪性リンパ腫の 3 症例を経験したので 報告する.

症例 $1: 80$ 歳, 男性.
既往歷: HBe 抗原陽性肝炎, 肝硬变, 陳旧性肺結核, 糖尿病, 薬剂性肝障害, 腎䘫胞, 急性腎不全.

家族歷；特記事項なし。

現病歷; ' 92 年 5 月初旬より 37 度台の発熱あり. 6 月 17日腹部エコーにて腹腔内のリンパ節腫脹多数めり．6 月27日結核性リンパ節炎疑いにて当院内科入院. 腹部 CT にて横隔膜脚，大動脈周囲のリンパ節腫大を認めた （図 1)，7月10日悪性リンパ腫疑いにて当科転科となる.

経過 : 初診時頸部リンパ節腫脹を認めたがその他耳鼻 咽喉科的所見に異常を認めなかった。 7 月10日頸部リン 瀄生検施行. スタンプ標本にてリンパ腫が確定し，病

甲府共立病院耳鼻咽喉科（山梨医科大学研究生） 

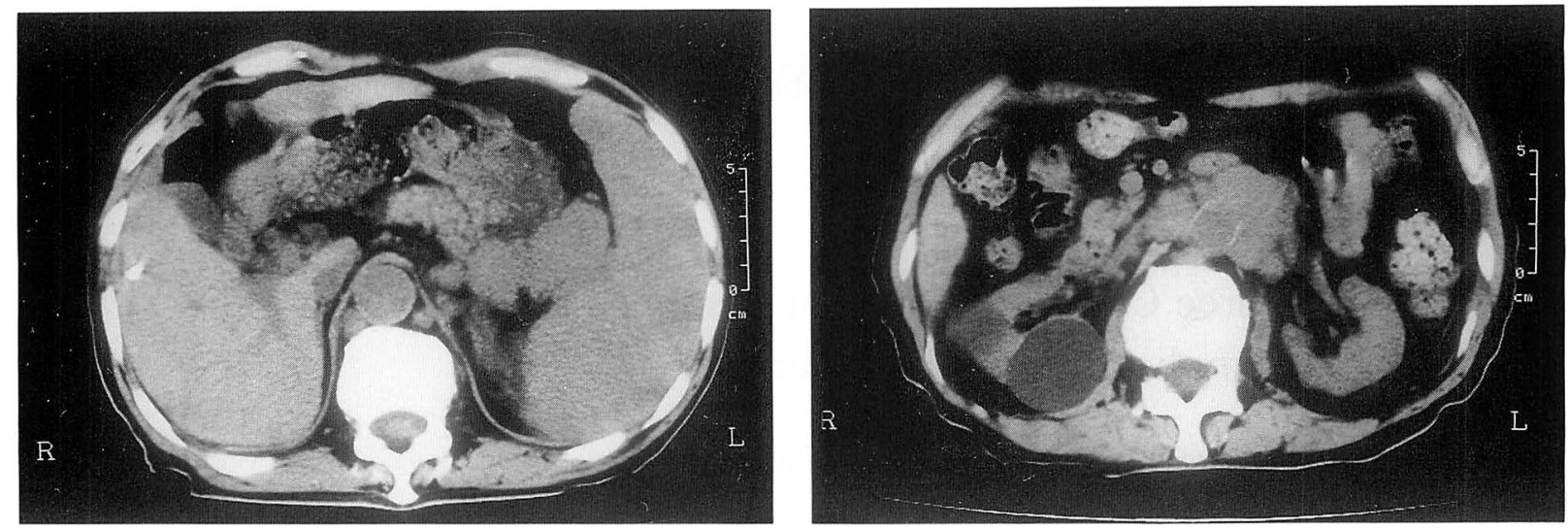

図 1 症例 1 . 化学療法前の腹部単純 CT

横隔膜脚，大動脈周囲リンパ節の腫大を認める.

理標本では非ホジキン病T細胞多形細胞型であった． 7 月11日化学療法 COD-BLAM N ${ }^{5}$ ) 開始(表 1). 7 月14日 白血球数低下のためガウンテクニック開始, 個室管理と なる。この頃より夜間せん妄出現.7月19日一過性高血 糖発作あり７月21日白血球数上昇し，ガウンテクニッ ク解除(図 2 )。胃静脈瘤, 食道静脈瘤破裂. 食道バルー ン留置. 7 月 22 日緊急内視鏡による硬化術施行. 肝性脳 症出現し, 内科治療とその後数次にわたる硬化療法施行 し一般状態 3 度程度にて 8 月 10 日退院となる。頸部リン パ節は消失し化学療法後の腹部 CT でも横隔膜脚のリン 分節はほぼ消失したが，大動脈周囲のリンパ節には残存 を認めた（図３）。胃静脈瘤からの出血の可能性が高いた
め化学療法は中止としたまま，一般状態 2 度までに回復 し現在外来管理中. 頸部リンパ節は消失したままである. 症例 $2: 70$ 歳, 男性.

既往歴 : 慢性閉塞性肺疾患, 気管支喘息.

家族歴：特記事項なし。

現病歴：’91年12月頃より喘息発作頻回となり同時に 上腹部痛出現し，次第に増悪してきたため’ 92 年 5 月 8 日当院内科初診となる. 初診時腹部エコーにて腹腔内リ ンパ節腫大多数認められる。 5 月 13 日慢性閉塞性肺疾患 治療および腹腔内リンパ節腫大精査・治療目的で入院と なる。 5 月 21 日上部消化管内視鏡にて高分化腺癌を噴門 直下, 胃角部に認めた. 腹部 CT にて傍大動脈・脺周囲・

表 1 COD-BLAM 療法

\begin{tabular}{|c|c|c|c|c|c|c|}
\hline \multicolumn{7}{|l|}{ Cycle } \\
\hline 1 & 2 & 3 & 4 & 5 & 6 & $7 \sim 12$ \\
\hline CTX & CTX & CTX & CTX & Adriamycin & Cytoxan & $M$ \\
\hline ADRIA & ADRIA & ADRIA & ADRIA & VCR & VCR & $A$ \\
\hline VCR & VCR & VCR & VCR & Decadron & Decadron & C \\
\hline BLE0 & BLE0 & BLE0 & BLE0 & & & $E$ \\
\hline DEXA & DEXA & DEXA & DEXA & & & \\
\hline PROCARB & PROCARB & PROCARB & PROCARB & & & \\
\hline $\begin{array}{l}1 \\
\text { Day }\end{array}$ & 22 & 43 & 64 & 85 & 106 & $127 \sim 180$ \\
\hline \multicolumn{4}{|c|}{$\begin{array}{l}\text { CTX = Cyclophosphamide } \\
\text { ADRIA = Adriamycin } \\
\text { VCR = Vincristine infusion } \\
\text { BLEO = Bleomycin infusion } \\
\text { DEXA = Decadron } \\
\text { PROCARB = Procarbazine }\end{array}$} & \multicolumn{3}{|c|}{$\begin{array}{l}M=\text { Methotrexate } \\
A=\text { Cytarabine } \\
C=\text { Citrovorum factor } \\
E=\text { Etoposide }\end{array}$} \\
\hline
\end{tabular}




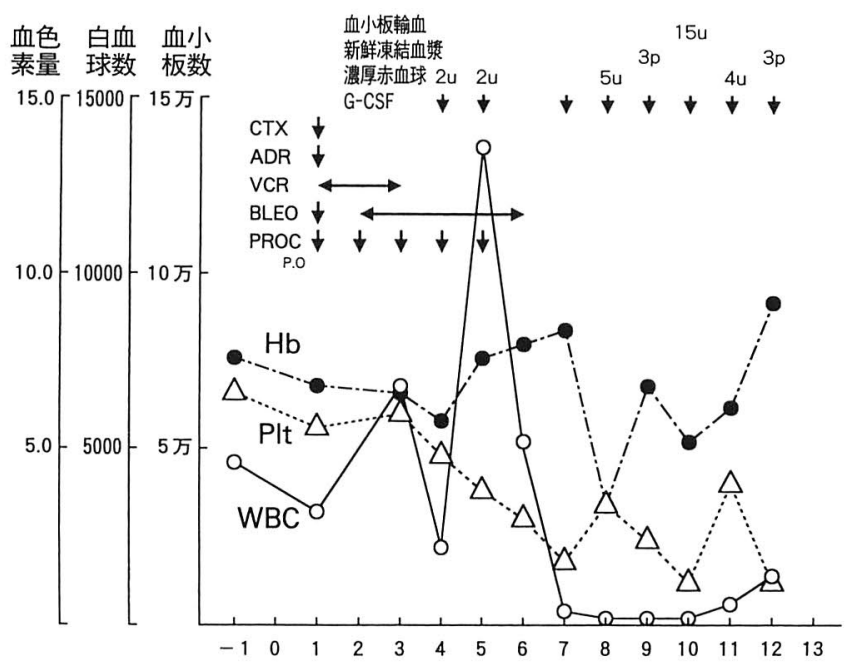

図 2 経過表
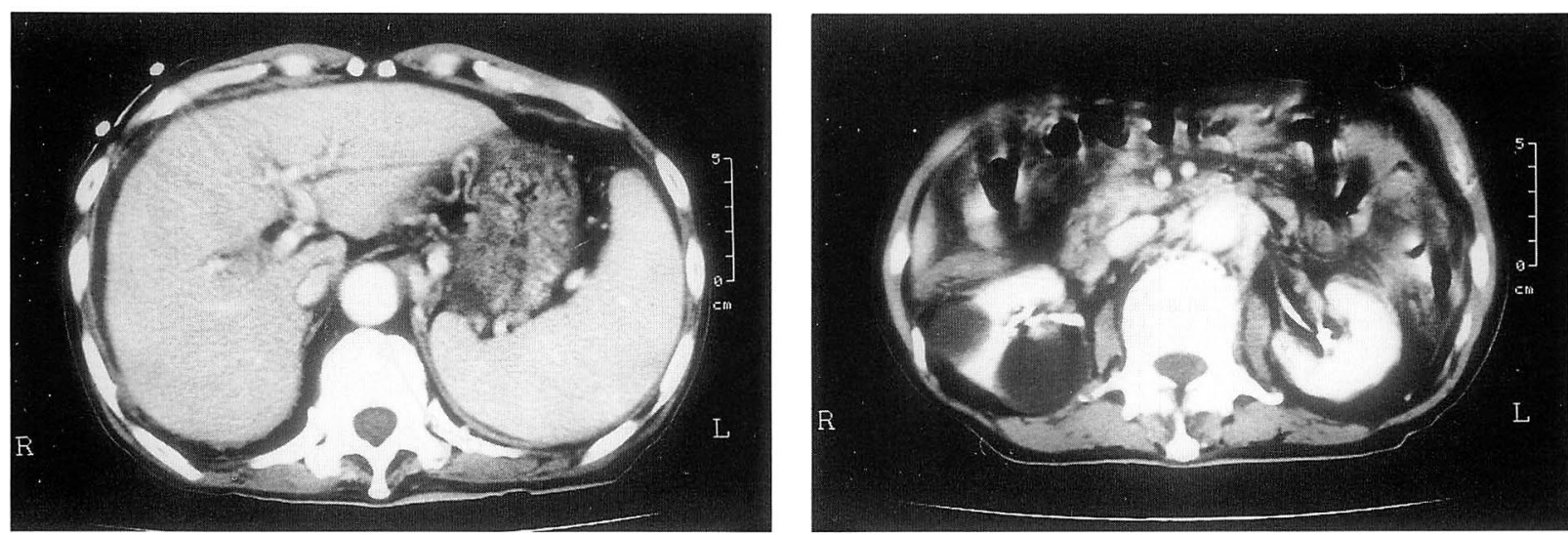

図 3 症例 1 . 化学療法後の腹部造影 CT

横隔膜脚リンパ節の腫大はほぼ消失しているが，大動脈周囲リンパ節には残存を認める.

肝門部リンパ節腫脹を認めた(図 4)。6月 2 日肺疾患が 改善したため手術不能例として一時退院となる。6月24 日吸引細胞診にて悪性リンパ腫が疑われたため当科紹介 され頸部リンパ節生検施行. 初診時頸部リンパ節腫脹と 口蓋扁桃 1 度腫大を認めた。 その他耳鼻咽喉科所見に異 常を認めなかった．病理標本にてホジキン病結節硬化型 と診断確定寸る. 7 月 9 日再入院し当科入転科となる.

経過；7月14日化学療法 COPP-ABV hybrid 療法開 始6)(表 2 , 図 5 )。9月14日化学療法 3 クール終了時の 上部消化管内視鏡にて胃角部病変の拡大を認めたため, 9 月 18 日外科に転科. 10 月 12 日胃全摘術施行. 胃角部 $40 \times 30 \mathrm{~mm}$ II a + II c, 胃体後部後壁 $20 \times 20 \mathrm{~mm}$ ボルマ
表 2 COPP-ABV Hybrid 療法

\begin{tabular}{lrll}
\hline \hline Cyclophophamide & $600 \mathrm{mg} / \mathrm{m}^{2}$ & IV & DAY 1 \\
Vincristine & $1.4 \mathrm{mg} / \mathrm{m}^{2}$ & IV & DAY 1 \\
Procarbazine & $100 \mathrm{mg} / \mathrm{m}^{2}$ & PO & DAY $1-7$ \\
Prednisone & $40 \mathrm{mg} / \mathrm{m}^{2}$ & PO & DAY $1-14$ \\
Doxorubicin & $35 \mathrm{mg} / \mathrm{m}^{2}$ & IV & DAY 8 \\
$\begin{array}{c}\text { Bleomycin } \\
\text { preceded by hydrocortisone }\end{array}$ & $100 \mathrm{mg}$ IV \\
$\begin{array}{c}\text { vincristine } \\
\text { repeatd every } 28 \mathrm{mg} / \mathrm{m}^{2}\end{array}$ IV Days & & DAY 8
\end{tabular}

ン I 型粘膜固有層に達する病変を認めた，郭清したリン

パ節および一部サンプリングしたリンパ節ともにホジキ ン病の所見を認めなかった。11月20日術後経過良好であ 

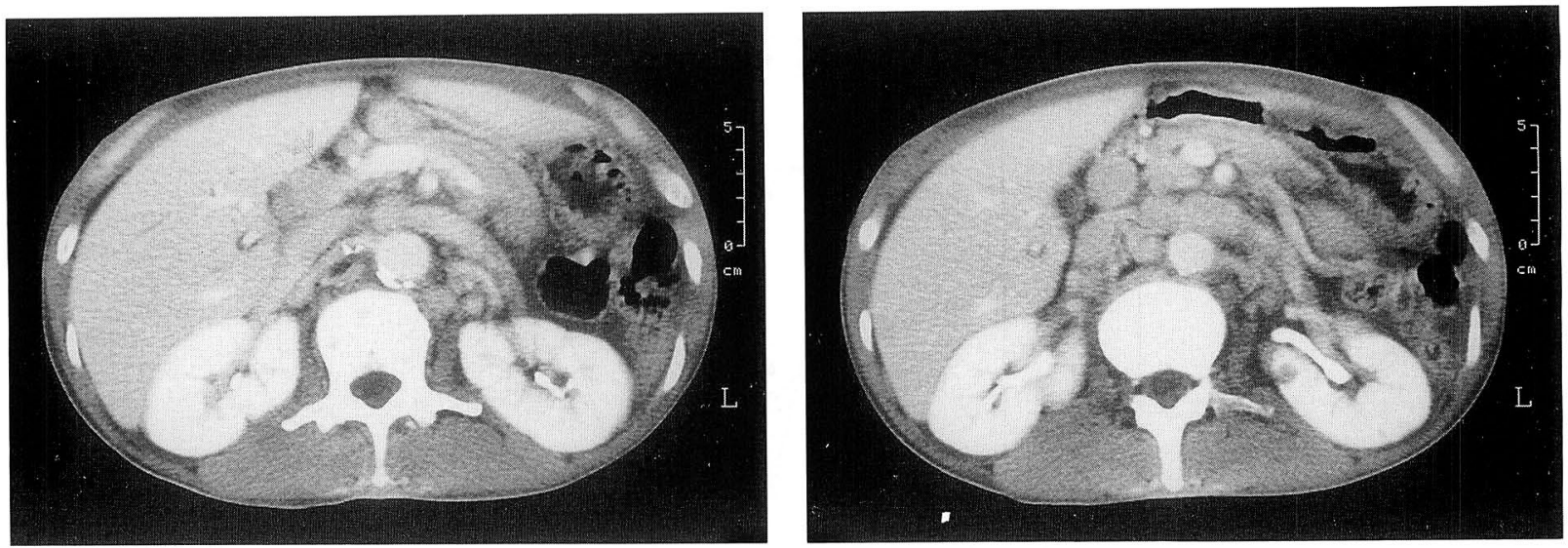

図 4 症例 2 , 化学療法前の腹部造影 CT 傍大動脈, 膵周囲, 肝門部リンパ節腫脹を認める.

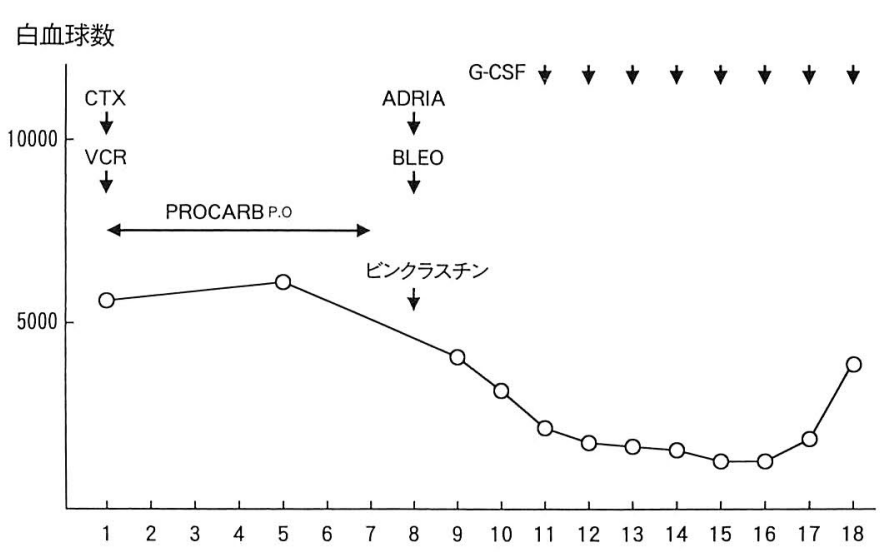

図 5 経過表

ったが MRSA 感染症の急性増悪を来し永眠される。

症例 $3: 65$ 歳, 女性.

既往歴 : 肝硬変, C 型肝炎, 食道静脈瘤.

家族歴：特記事項なし。

現病歴 : ’92年 2 月ごろより右顎下部の腫大を認め次 第に増大してきたため 5 月 30 日当科初診となる. 初診時 右嶺下部に $40 \times 50 \mathrm{~mm}$ の腫瘍あり.また左反回神経麻 痺を認めた。 その他耳鼻咽喉科的所見に異常を認めなか った．頸部 CT にて右顎下部に $40 \times 50 \mathrm{~mm}$ の充実性腫 瘍を認めた(図 6 ).

経過：6月 4 日吸引細胞診施行, 悪性リンパ腫, class N.6月 15 日当科入院. 6 月 18 日顎下部腫瘍摘出 術施行. 病理標本より非ホジキン病T細胞びまん性大細
胞型之診断. 6 月24日化学療法開始 COD-BLAM N 開 始5). 現在も合併症の増悪なく化学療法中である(図 7 , 8 ).

\section{考察}

高歯者では臓器障害が強く現れる要因は常に潜在する と思われるが，単に高齢といらことだけで副作用が強く 出現することは少ないと言われる2)314)。ただ骨髄障害だ けは骨髄が脂肪組織によって置換され予備能が低下して いるため高齢者で強い277). 当科では’90年より60歳以上 の非ホジキン悪性リンパ腫のらち中等度, 高度悪性群に 対して COD-BLAM N 療法5)を施行している. 肝, 腎, 骨髄に合併症を有しない70歳までの症例では薬剤の減量 


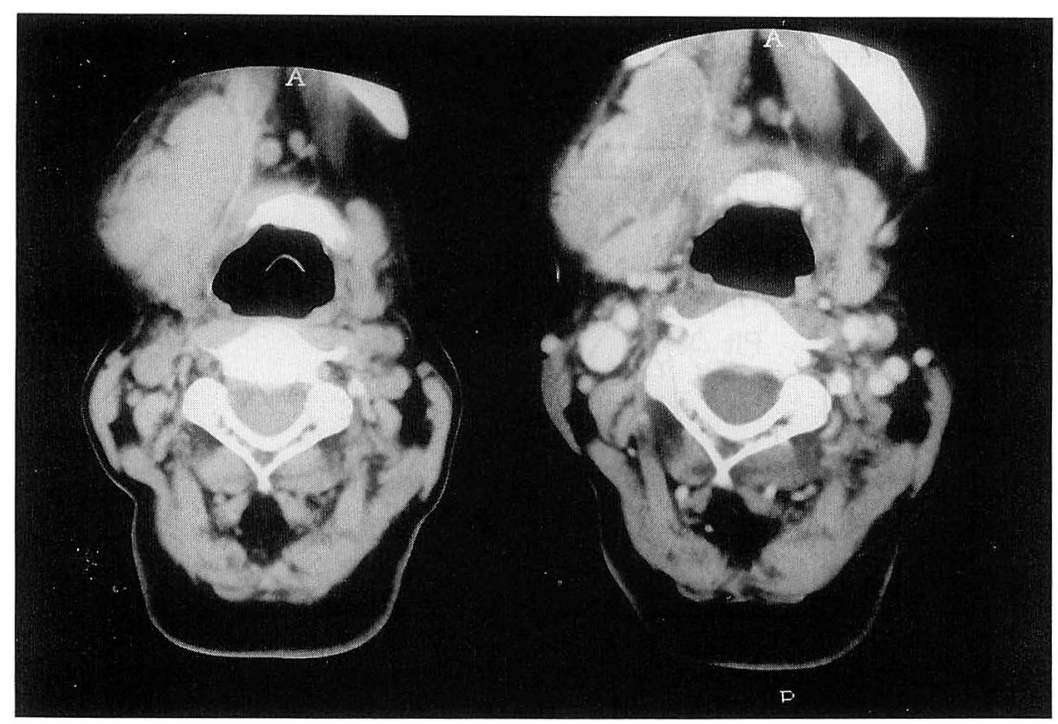

図 6 症例 3. 化学療法前の頸部 CT

右顎下部に $40 \times 50 \mathrm{~mm}$ の充実性腫瘍を認める.

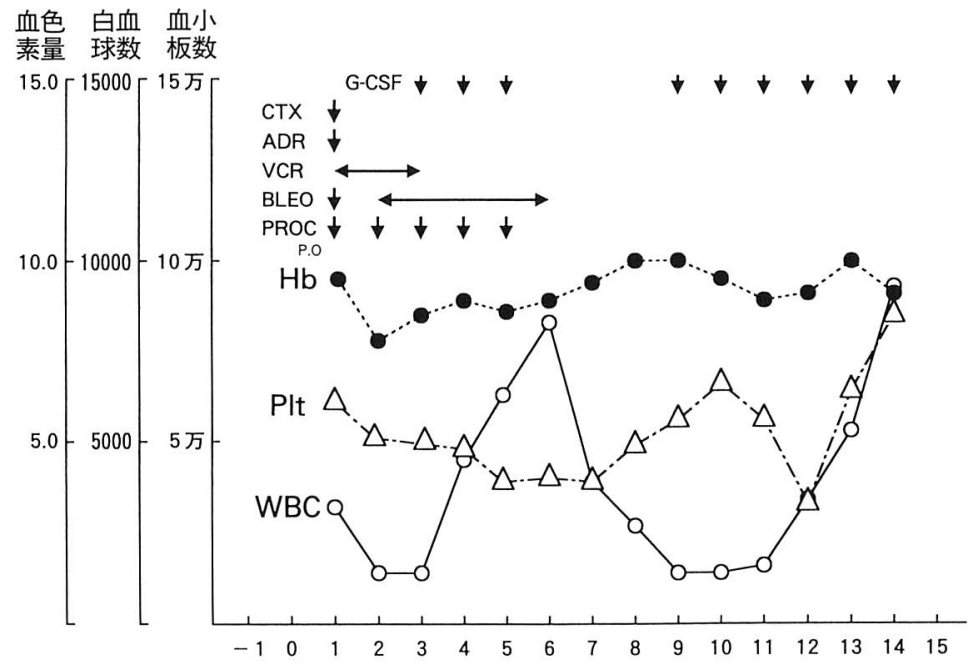

図 7 経過表

を要していない。症例 1 扣よび 3 は, 脾腫大をともなら 肝硬変症例であり通常でも白血球数, 血小板数低值であ り, 化学療法当日より,さらに数值の低下を認めた。 ド キソラビシン等の肝代謝の遅延 ${ }^{8)}$, 脾機能の亢進, 骨髄 の予備能の低下等によるものと思われた. 白血球数の減 少に対しては G-CSF の投与が有効であった。症例 3 で は化学療法の当日より G-CSF の連日投与を， 3 クール 以降施行した(図 8 ). 年齢, 葴器機能によって抗癌剤投
与量を調節する必要があり 4)910) 症例 1 で約 20\%, 症例 3 で約10\%減量した. 症例 1 では初回投与量としては過 量投与であった。各種臓器の機能評価に加えて他の悪性 腫瘍等の合併症の有無の検索も必須であるが, 症例 2 で は化学療法前評価不十分で, 静脈瘤が破裂するまでその 可能性を察知できなかった。また，高齢者の精神障害に ついても, 化学療法前の評価が必要と思われる11). 我々 の症例でも症例 1 では肝性脳症に加えて夜間せん妄も出 


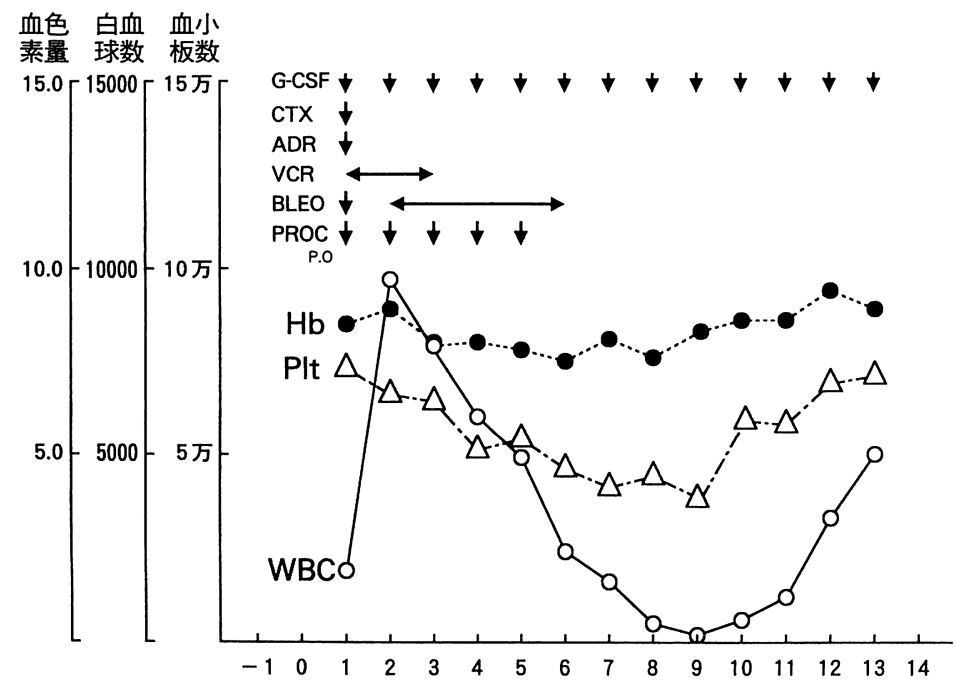

図 8 経過表

現し, 老人性痴呆が増悪し症例 2 でもらつ傾向が出現し た. 高齢者の精神障害に対しては特別の配慮が必要と思 われた12)13). 症例 2 は慢性閉塞性肺疾患に加えて早期胃 癌を合併していたが，病期のすすんだ悪性リンパ腫から 治療を開始した．外科治療を優先する考え方も存在した.

\section{結語}

重篤な合併症をもった高齡者の悪性リンパ腫 3 症例を 経験したので報告した. 高齢者といえども各種臓器の機 能評価を含めた全身状態の評価, 合併症の存否とその程 度の評価を化学療法前に十分行ない副作用対策, 支持療 法を行えば積極的治療が十分可能であると思われた.

\section{参考文献}

1 ) 前田迪郎, 池口正英, 貝原信明, 他 : 高齢者手術療法の問 題点. 癌と化療 $19: 1786 \sim 1791,1992$.

2) 古江 尚: 高齢者癌の化学療法. 癌と化療 19:1796 1800, 1992.

3 ) 斎藤 博, 溝口秀昭 : 高齢者造血器腫瘍とその治療. 癌と 化療 $19: 1801 \sim 1807,1992$.

4 ) 森県由美 : 高齢者覀性リンパ腫の特徵と治療. 医学のあゆ み $152: 968 \sim 972,1990$.

5 ) Coleman M, Silver RT, Pasmantier MW, et al : Advances in chemotherapy for large cell lymphoma : Semin Hematol $24: 8 \sim 20,1987$.
6) Connors JM and Klimo P : MOPP/ABV hybrid chemotherapy for advanced Hodgkin's disease, Semin. Hematol $24: 35 \sim 40,1987$.

7 ) Balducci L, Parker M, Sexton W, et al : Pharmacology of antineoplastic agents in the elderly patients. Semin Oncol $16 ; 76 \sim 84,1989$.

8 ) Robert J and Hoerni B : Age dependence of early-phase phamacokinetics of doxorubicin, Cancer Res $43: 4467 \sim$ 4469, 1983

9) Heinz R, Pawlicki M, Losonczy M, et al : Initial chemotherapy with an age-adjusted CHOP schedule in Non-Hodgkin lymphoma with unfavorable prognosis. Haematologica $71: 473 \sim 479$.

10）新井 望, 原 明博, 金子晴生, 他: 非ホジキンリンパ腫 に対する COP-BLAM 療法の検討. 日老医会誌 $27: 357 \sim$ $361,1990$.

11）長谷川和夫, 加藤伸司, 下垣 光, 他 : 改訂長谷川式簡易 知能評価スケールの作成. 老年精医 $2: 1339 \sim 1347,1991$.

12）穂積 慧, 大川匡子, 菱川泰夫, 他 : 老年期痴呆の生体り ズムと光療法. Dementia $4: 333 \sim 342,1990$.

13）黒沢 尚, 吉河達佑: 手術後の精神障害とその対策. 臨外 $44: 191 \sim 196,1989$.

$$
\left(\begin{array}{l}
\text { 別刷請求先 : 永沼久夫 } \\
\text { 干400 山梨県甲府市宝1-9-1 } \\
\text { 甲府共立病院耳鼻科 }
\end{array}\right)
$$

